\title{
Pokémon GO and Physical Activity in Asia: Multilevel Study
}

Ben D Ma ${ }^{1,2}$, MSc; Sai Leung $\mathrm{Ng}^{1}, \mathrm{PhD}$; Tim Schwanen ${ }^{3}, \mathrm{PhD}$; John Zacharias ${ }^{4}$, PhD; Mudi Zhou ${ }^{5}$, BSc; Ichiro Kawachi ${ }^{6}, \mathrm{MBChB}, \mathrm{PhD}$; Guibo $\mathrm{Sun}^{7}, \mathrm{PhD}$

\author{
${ }^{1}$ Department of Geography and Resource Management, The Chinese University of Hong Kong, Hong Kong, China (Hong Kong) \\ ${ }^{2}$ Institute of Space and Earth Information Science, The Chinese University of Hong Kong, Hong Kong, China (Hong Kong) \\ ${ }^{3}$ Transport Studies Unit, School of Geography and Environment, University of Oxford, Oxford, United Kingdom \\ ${ }^{4}$ College of Architecture and Landscape, Peking University, Beijing, China \\ ${ }^{5}$ Department of Mathematics, Imperial College London, London, United Kingdom \\ ${ }^{6}$ Department of Social and Behavioral Sciences, TH Chan School of Public Health, Harvard University, Boston, MA, United States \\ ${ }^{7}$ Department of Urban Planning and Design, Faculty of Architecture, The University of Hong Kong, Hong Kong, China (Hong Kong)
}

\section{Corresponding Author:}

Sai Leung Ng, PhD

Department of Geography and Resource Management

The Chinese University of Hong Kong

2nd Floor, Wong Foo Yuan Building

Hong Kong, 999077

China (Hong Kong)

Phone: 85239436527

Fax: 85226035006

Email: slng@cuhk.edu.hk

\section{Abstract}

Background: Physical activity has long been considered as an important component of a healthy lifestyle. Although many efforts have been made to promote physical activity, there is no effective global intervention for physical activity promotion. Some researchers have suggested that Pokémon GO, a location-based augmented reality game, was associated with a short-term increase in players' physical activity on a global scale, but the details are far from clear.

Objective: The objective of our study was to study the relationship between Pokémon GO use and players' physical activity and how the relationship varies across players with different physical activity levels.

Methods: We conducted a field study in Hong Kong to investigate if Pokémon GO use was associated with physical activity. Pokémon GO players were asked to report their demographics through a survey; data on their Pokémon GO behaviors and daily walking and running distances were collected from their mobile phones. Participants $(\mathrm{n}=210)$ were Hong Kong residents, aged 13 to 65 years, who played Pokémon GO using iPhone 5 or 6 series in 5 selected types of built environment. We measured the participants' average daily walking and running distances over a period of 35 days, from 14 days before to 21 days after game installation. Multilevel modeling was used to identify and examine the predictors (including Pokémon GO behaviors, weather, demographics, and built environment) of the relationship between Pokémon GO use and daily walking and running distances.

Results: The average daily walking and running distances increased by $18.1 \%$ (0.96 km, approximately 1200 steps) in the 21 days after the participants installed Pokémon GO compared with the average distances over the 14 days before installation $(P<.001)$. However, this association attenuated over time and was estimated to disappear 24 days after game installation. Multilevel models indicated that Pokémon GO had a stronger and more lasting association among the less physically active players compared with the physically active ones $(P<.001)$. Playing Pokémon GO in green space had a significant positive relationship with daily walking and running distances $(P=.03)$. Moreover, our results showed that whether Pokémon GO was played, the number of days played, weather (total rainfall, bright sunshine, mean air temperature, and mean wind speed), and demographics (age, gender, income, education, and body mass index) were associated with daily walking and running distances.

Conclusions: Pokémon GO was associated with a short-term increase in the players' daily walking and running distances; this association was especially strong among less physically active participants. Pokémon GO can build new links between humans and green space and encourage people to engage in physical activity. Our results show that location-based augmented reality games, such as Pokémon GO, have the potential to be a global public health intervention tool. 
(J Med Internet Res 2018;20(6):e217) doi: 10.2196/jmir.9670

\section{KEYWORDS}

physical activity; Pokémon Go; public health intervention; exergame; weather

\section{Introduction}

As a Pokémon GO player, the first author of this paper walked $1526 \mathrm{~km}$ over 5 continents (Asia, Africa, Europe, North America, and South America) during the course of the game. This substantially increased his walking activity. His case may be that of an outlier, but increased walking is very common among Pokémon GO players. Pokémon GO is a location-based augmented reality (AR) game, which was launched in July 2016. Impressively, it receives 65 million monthly active players and has recorded more than 650 million app downloads within 6 months [1]. Pokémon are virtual creatures that inhabit the fictional Pokémon World. Pokémon GO allows players to locate, capture, and battle Pokémon on their mobile devices, as if the Pokémon were in the same real-world locations as the players. As players move around their real world, their avatars in the game move within the in-game map based on real world geographical locations. The in-game map contains many features such as "Gyms" and "Pokéstops," where players can get Poké balls and other items to catch and battle with Pokémon. To play this game, players need to move around in the real world and not be sedentary. By May 2017, 9\% of the global population installed Pokémon GO and traveled more than 15.8 billion $\mathrm{km}$ while playing Pokémon GO [2].

In this study, we sought to measure the relationship between Pokémon GO use and the players' physical activity and how this relationship varied across players. Physical activity has long been considered an essential component of a healthy lifestyle [3-5]. Although many efforts to promote physical activity [5-7] have been undertaken, there is no effective global intervention for physical activity promotion [8]. Physical inactivity is the second-leading cause of preventable death worldwide, next to smoking [5].

The literature indicates that physical activity is affected by various variables, such as demographics [9-11], body mass index (BMI) [12,13], weather [14-16], and built environment [17-19]. Recently, increasing research suggested that new technologies, especially "gamified" physical activity interventions, are used to promote physical activity [20]; however, it was not until 2016 that Pokémon GO provided the first glimpse of how to intervene for the promotion of physical activity on a global scale.

Past studies found that Pokémon GO was associated with short-term increases in players' physical activity levels. The existing literature can be mainly divided into 2 groups. Objectively-collected physical activity data indicated that there was an increase in the daily number of walking steps among the Pokémon GO players after game installation [21,22]. Studies using self-reported data indicated that players spent more time outside and performed more physical exercise because of Pokémon GO [23-26]. Other research included studies on Pokémon GO players' motivations [27,28], experiences while playing Pokémon GO [29], and potential adverse effects associated with playing Pokémon GO [30,31].

However, there remain 2 major research gaps. First, physical activity on each day is not only determined by players' demographics and Pokémon GO behaviors (such as whether Pokémon GO was played, and the number of days played) but also by weather and built environment. Inclement or extreme weather can be physical activity barriers [15]. Further, built environment is the essential element for location-based AR games because the games are built based on the actual physical world environment. However, existing research failed to take them into account when investigating the relationship between Pokémon GO use and physical activity.

Second, although some researchers suggested that the association between Pokémon GO and physical activity varies among different populations [24,25,32,33], to date, little research has been performed on these potential differences among players. Howe et al focused on young adults [21]; Althoff et al studied wearable Microsoft product users [22]; Kogan et al focused their study on dog owners [34]; and Wong et al researched university students [26]. Asia is home to $60 \%$ of the world's population [35]; although Pokémon GO has been suspended in Mainland China, there are still considerable numbers of Pokémon GO players in other parts of Asia. However, most studies were conducted in Western countries, and there are no objective studies of Pokémon GO and physical activity in Asia.

Therefore, we used a multilevel modeling approach to answer 2 main research questions. They are as follows:

- What is the relationship between Pokémon GO use and players' physical activity levels?

- How does the association between Pokémon GO and physical activity vary across players with different physical activity levels?

\section{Methods}

\section{Research Design}

We conducted a field survey in August 2016 during the first month after Pokémon GO was launched in Hong Kong. Researchers approached Pokémon GO players at 5 study sites that represented 5 typical types of built environment. Participants' data, including sex, age, income, education level, BMI $\left(\mathrm{kg} / \mathrm{m}^{2}\right)$, and the start date of Pokémon GO, were collected using a questionnaire. Participants' physical activity data, specifically daily walking and running distances, were captured from their iPhone "health" app pages by taking pictures of their screens. Eventually, we compiled a data set covering the period from 14 days before and 21 days after the installation of Pokémon GO. Weather data were collected from Hong Kong Observatory, including total rainfall $(\mathrm{mm})$, bright sunshine 
(hours), mean air temperature $\left({ }^{\circ} \mathrm{C}\right)$, and mean wind speed $(\mathrm{km} / \mathrm{h})$.

Table 1. Descriptions of study sites.

\begin{tabular}{lll}
\hline Study site & Type of built environment & Description \\
\hline Central & Office area & Land used for administration, or clerical, technical, professional, or other like business activity \\
Wan Chai & Mixed use area & Land used for mixed uses \\
Victoria Park & Green space & Integrated park consisting of playgrounds, sitting-out areas or public/mini sports grounds \\
Wong Tai Sin & Residential area & Land used to for residential accommodations \\
Causeway Bay & Retail premises & Land used to: (a) sell goods by retail or by retail and wholesale; (b) sell services; or (c) hire goods
\end{tabular}

The survey was conducted by our researchers on a face to face basis with each participant in the study areas. All participants provided written informed consent to participate prior to survey conduction. Participants received a Pokémon toy as a token of appreciation for completing the study. All data collected were anonymized, and the participants' names and home addresses were not collected.

\section{Study Population}

We approached Pokémon GO players while they were playing Pokémon GO within the study sites. To ensure the reliability and consistency of data, only iPhone 5 s or 6 series users with qualified daily walking and running distances in their iPhone "health" app were included in this study. We excluded individuals who did not complete the questionnaire, were not iPhone $5 \mathrm{~s}$ or 6 users, and those who were iPhone users but were unable to provide their daily walking and running distances data. We also excluded respondents with insufficient Pokémon GO levels to unlock the primary functions of the game. The primary function of the game was to reach level 5 and gain access to the Gyms.

\section{Study Sites}

We used 5 study sites, which represented 5 typical types of built environment in Hong Kong, namely, a green space, an office area, a residential area, a mixed-use area, and a retail location (Table 1). For each built environment, we selected a 200-m radial zone based on the surrounding land use [36] and set $\geq 60 \%$ of the surrounding land use belonging to that type of built environment as the criterion for the site selection through a GIS platform [37].

\section{Daily Walking and Running Distances}

Daily walking and running distance data represented the daily physical activities of Pokémon GO players. To compare players' physical activities before and after installation, we used the average walking and running distances each day over a period of 35 days (14 days before to 21 days after game installation). We estimated 95\% CI 5.8-6.0 through a bootstrap with 500 resamples of daily walking and running distances. If there were no data on a given day, which meant the player probably did not touch his or her phone at all, or there were problems with the phone, we ignored the data recorded on that day. We excluded 15 observations from the analysis because the data values were empty.

\section{Multilevel Modeling}

Multilevel modeling was employed to investigate the difference of association between Pokémon GO and daily walking and running distances across players. We have multiple observations of daily walking and running distances of the same individual (from 14 days before to 21 days after the game installation); based on this cluster data structure, multilevel modeling was applied to investigate the relationship between Pokémon GO use and physical activity. At observation level, each observation has its own observation-level attributes, including whether Pokémon GO was played, the number of days played, total rainfall (mm), bright sunshine (hours), mean air temperature (degree Celsius), and mean wind speed $(\mathrm{km} / \mathrm{h})$. At player level, age, income, gender, education, BMI $\left(\mathrm{kg} / \mathrm{m}^{2}\right)$, and built environment variables were added. Further, interdependencies among different player levels were taken into account through multilevel modeling. We transferred parts of variables into dummy variables based on questions that we intended to investigate. MLwiN V.3.0 was used to conduct the multilevel modeling analysis.

\section{Funding, Ethical Approval, and Data Sharing}

This research received no specific grant from any funding agency in the public, commercial, or not-for-profit sectors. This study was approved by Survey and Behavioral Research Ethics Committee at The Chinese University of Hong Kong on August 4,2016 . The statistical code and dataset are available from the corresponding author.

\section{Results}

\section{Study Populations and Sites}

Overall, 210 Pokémon GO players were included in this study; Table 2 shows the profile of the participants. We identified 2964 individuals as Pokémon GO players while they were playing Pokémon GO within the study sites. Of these, 1248 answered our questionnaire and 1028 players were excluded because they were not iPhone $5 \mathrm{~s}$ or 6 users or were iPhone users but unable to provide their daily walking and running distance data. Additionally, we excluded those who did not complete the questionnaire $(n=7)$ or who were unable to unlock the primary functions of the game $(n=3)$. 
Table 2. Characteristics of Pokémon GO players $(\mathrm{N}=210)$.

\begin{tabular}{|c|c|}
\hline Characteristic & Value \\
\hline Age (years), mean (SD) & $26.1(8.7)$ \\
\hline \multicolumn{2}{|l|}{ Age group (years), n (\%) } \\
\hline $13-17$ & $25(11.9)$ \\
\hline $18-23$ & 67 (31.9) \\
\hline $24-29$ & $43(20.5)$ \\
\hline $30-35$ & $35(16.7)$ \\
\hline $36-50$ & $21(10.0)$ \\
\hline$>51$ & $2(1.0)$ \\
\hline Female, $\mathrm{n}(\%)$ & $71(33.8)$ \\
\hline \multicolumn{2}{|l|}{ Education, n (\%) } \\
\hline High school or lower & $70(33.3)$ \\
\hline College or higher & $118(56.1)$ \\
\hline \multicolumn{2}{|l|}{ Monthly income (HKD), n (\%) } \\
\hline$<5000$ & $65(31.0)$ \\
\hline $5000-10000$ & $12(5.7)$ \\
\hline $10001-15000$ & $41(19.5)$ \\
\hline $15001-20000$ & $30(14.3)$ \\
\hline $20001-30000$ & $18(8.6)$ \\
\hline$>30000$ & $18(8.6)$ \\
\hline \multicolumn{2}{|l|}{ Site, n $(\%)$} \\
\hline Office (Central) & $33(15.7)$ \\
\hline Mixed use (Wan Chai) & $48(22.9)$ \\
\hline Green space (Victoria Park) & $46(21.9)$ \\
\hline Residential (Wong Tai Sin) & $55(26.2)$ \\
\hline Retail premises (Causeway Bay) & $28(13.3)$ \\
\hline \multicolumn{2}{|l|}{ Body mass index (BMI; kg/m²), n (\%) } \\
\hline Underweight $(\mathrm{BMI}<18.5)$ & $57(27.1)$ \\
\hline Normal $(18.5 \leq \mathrm{BMI}<25)$ & $121(57.6)$ \\
\hline Overweight/obese ( $25 \leq \mathrm{BMI})$ & $16(7.6)$ \\
\hline Daily walking and running distances in 2 weeks before installation of Pokémon GO (km), mean (SD) & $5.4(3.5)$ \\
\hline
\end{tabular}

\section{Daily Walking and Running Distances Before and After the Game Installation}

Figure 1 shows the change in average daily walking and running distances of the Pokémon GO players in the period from 14 days before to 21 days after game installation. The average distance increased by $18.1 \%(0.96 \mathrm{~km})$, from $5.30 \mathrm{~km}$ (SD 2.12) (before installation) to $6.26 \mathrm{~km}$ (SD 2.45) (after installation). A comparison of means shows that Pokémon GO was associated with increases in daily walking and running distances $(F=33.825, P<.001)$. We observed a decrease in daily walking and running distances during the period from the 5th to 8th day after installation. During that period, Hong Kong's weather deteriorated because of the influence of the typhoon Nida.

\section{Pokémon GO and Physical Activity across Players}

The results of multilevel models are shown in Table 3. A null model, a model without any input variances, which simply describes the variance at each level, was conducted first. We found that $22.5 \%$ of the variance was explained at the observation level, and this provided justification for proceeding to the subsequent analysis. 
Figure 1. Average daily walking and running distance before and after the installation of Pokémon GO. Error bars correspond to bootstrapped $95 \%$ confidence intervals

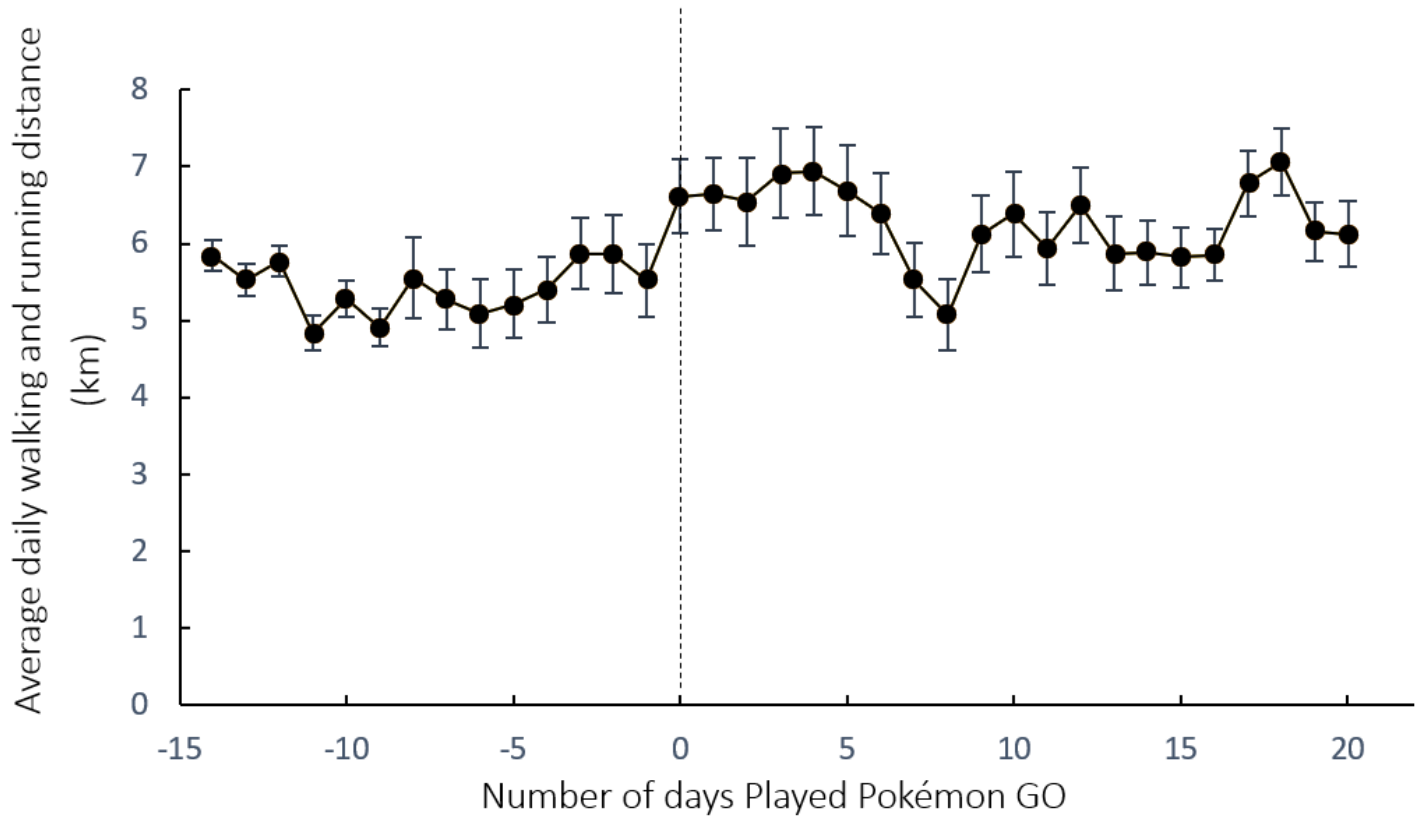

Model 1 contains observation-level variables. In model 2 , the player-level variables were added and analyzed together with the observation-level variables (Table 3). In model 3, assuming that all other variables in the model were held constant, the relation between Pokémon GO behaviors and dependent variables were investigated. In model 4 , on the basis of model 3 , the interactions of Pokémon GO use (or no Pokémon GO use) and built environment were included (Table 4).

The results of multilevel models showed that the observation-level variables (including whether Pokémon GO was played, the number of days played, total rainfall, bright sunshine duration, mean air temperature, and mean wind speed) were significantly related to daily walking and running distances. Whether Pokémon GO was played $(P=.005)$ and bright sunshine duration $(P=.01)$ were significantly associated with the increased daily walking and running distances. Conversely, the number of days played $(P<.001)$, total rainfall $(P=.003)$, mean air temperature $(P=.01)$, and mean wind speed $(P=.04)$ were negatively correlated with daily walking and running distances. At the player level, our results indicated that players who were male, had high school or lower education, and exhibited normal BMI $\left(\mathrm{kg} / \mathrm{m}^{2}\right)$ were likely to have higher daily walking and running distances (Table 4). Furthermore, playing Pokémon
GO in green space was associated with higher daily walking and running distances $(P=.03)$.

Playing Pokémon GO was significantly associated with increased daily walking and running distances $(P=.005)$, whereas the number of days played was significantly associated with decreased daily walking and running distances $(P<.001)$. The results showed that the association between Pokémon GO and daily walking and running distances attenuated over time and may have dissappeared after players played Pokémon GO for 24 days (Table 4$)$.

Most importantly, our results indicate that the effects of playing Pokémon GO are somewhat stronger for players with lower levels of daily physical activity and slightly stronger for those who have played the game for fewer days. These findings are obtained when the estimated effects of playing Pokémon GO and number of days played are allowed to vary across individuals in the sample. The negative estimate of the covariance of playing Pokémon GO and intercept $(-0.008$ in Model 4) captures the stronger health benefits of playing among respondents with shorter walking and running distances. The estimated covariance between days played and whether Pokémon GO was played of -0.00057 shows that those playing the game for a shorter period of time have, all else equal, experienced slightly less health benefits. 
Table 3. Multilevel models of Pokémon GO and daily walking and running distances (km) models 1 and 2.

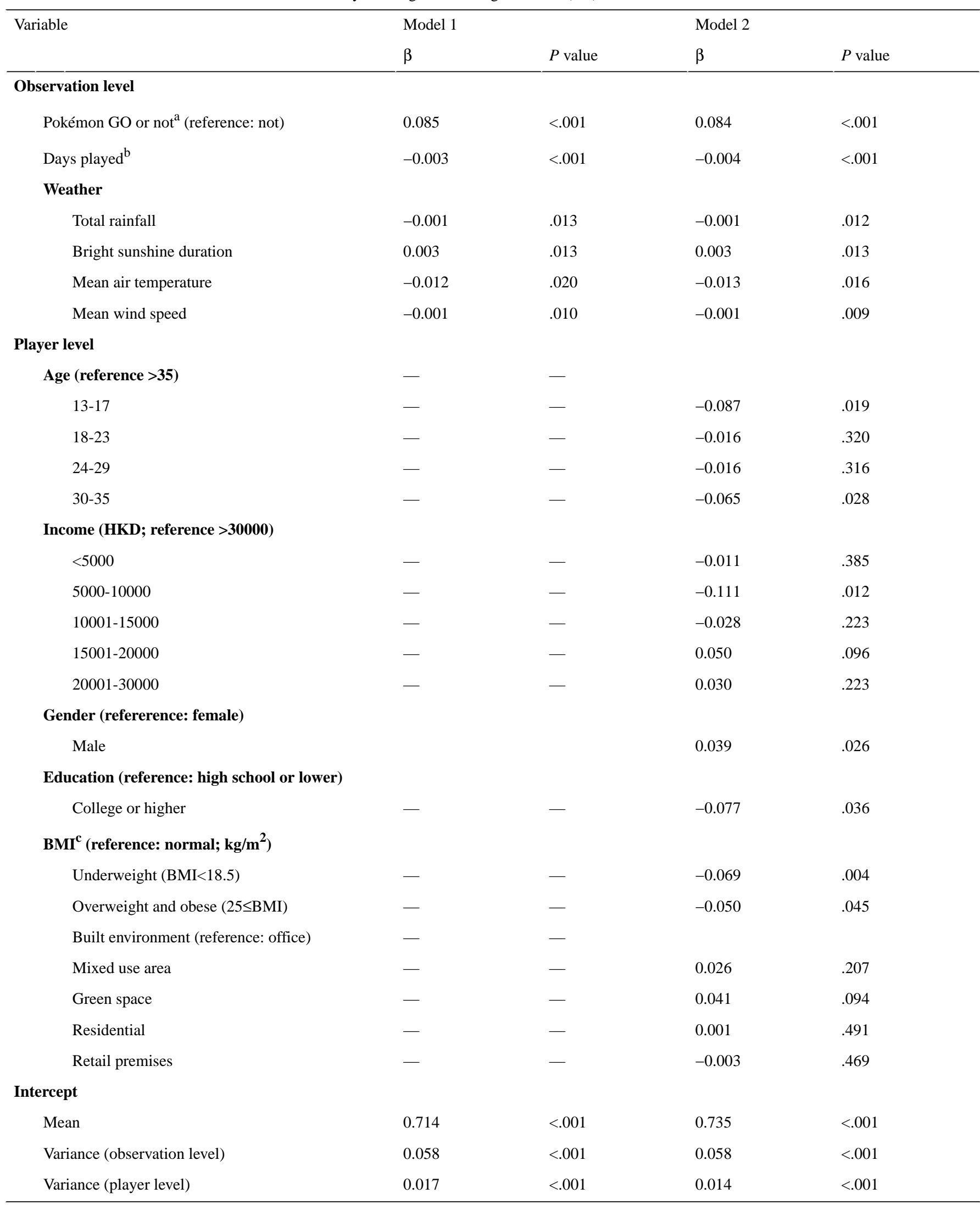

af the data belonged to the date before the participant played Pokémon GO, this value would be 0 . Otherwise, it would be 1 .

${ }^{b}$ If the data belonged to the date before the participant played Pokémon GO, this value would be 0 . Otherwise, it would be the number of days he or she played.

${ }^{\mathrm{c}} \mathrm{BMI}$ : body mass index. 
Table 4. Multilevel models of Pokémon GO and daily walking and running distances (km) models 3 and 4.

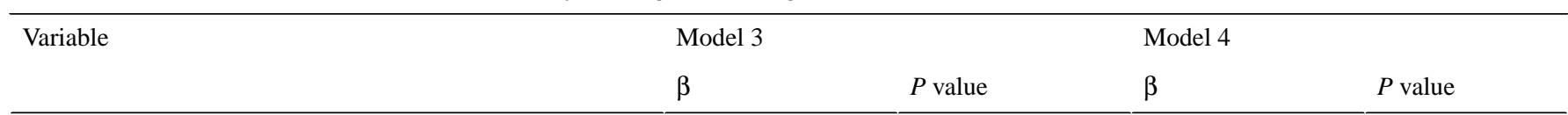

\section{Observation level}

Pokémon GO or not ${ }^{\mathrm{a}}$ (reference: not)

Mean

Variance (player level)

Covariance with intercept (player level)

\section{Days played $^{b}$}

Mean

Variance (player level)

Covariance with intercept (player level)

Covariance with Pokémon GO (player level)

\section{Weather}

Total rainfall

Bright sunshine duration

Mean air temperature

Mean wind speed

\section{Players level}

Age (reference $>35$ )

$13-17$

$18-23$

24-29

30-35

Income (HKD; reference >30000)

$<5000$

5000-10000

10001-15000

15001-20000

20001-30000

Gender (reference: female)

Male

Education (reference: high school or lower)

College or higher

BMI $^{c}$ (reference: normal; $\mathrm{kg} / \mathrm{m}^{2}$ )

Underweight $(\mathrm{BMI}<18.5)$

Overweight and obese $(25 \leq \mathrm{BMI})$

Built environment (reference: office)

Mixed use area
Green space
Residential
Retail premises
eractions (reference: Pokémon GO x Office)

$\begin{array}{llll}0.093 & <.001 & 0.072 & .005 \\ 0.018 & <.001 & 0.017 & <.001 \\ -0.009 & <.001 & -0.008 & <.001\end{array}$

$-0.004$

$<.001$

$-0.005$

$<.001$

0.000096

$<.001$

0.000097

$<.001$

0.000068

.346

0.000059

.346

$-0.00058$

.004

$-0.00057$

.004

$-0.001$

.003

$-0.001$

.003

0.003

.011

0.003

.012

$-0.013$

.010

$-0.013$

.011

$-0.001$

.037

$-0.001$

.036

$-0.068$

.048

$-0.067$

.047

$-0.007$

.414

$-0.007$

.415

$-0.010$

.380

$-0.009$

.389

$-0.061$

.031

$-0.061$

.031

$-0.024$

.263

$-0.024$

.265

$-0.122$

.005

$-0.122$

.005

$-0.041$

.123

$-0.040$

.125

0.044

.112

0.046

.103

0.027

.239

0.028

.227

0.040

.019

0.041

.017

$-0.075$

.037

$-0.073$

.040

$-0.074$

.002

$-0.073$

.002

$-0.052$

.036

$-0.051$

.038

0.032

.195

0.028

.191

0.044

.068

0.001

.494

$-0.001$

.490

$-0.018$

.309

0.003

.460

0.001

.491 


\begin{tabular}{|c|c|c|c|c|}
\hline \multirow[t]{2}{*}{ Variable } & \multicolumn{2}{|c|}{ Model 3} & \multicolumn{2}{|c|}{ Model 4} \\
\hline & $\beta$ & $P$ value & $\beta$ & $P$ value \\
\hline Pokémon GO * Mixed use & - & - & 0.006 & .437 \\
\hline Pokémon GO * Green space & - & - & 0.068 & .028 \\
\hline Pokémon GO * Residential & - & - & 0.027 & .210 \\
\hline Pokémon GO * Retail premises & - & - & -0.010 & .406 \\
\hline \multicolumn{5}{|l|}{ Intercept } \\
\hline Mean & 0.733 & $<.001$ & 0.733 & $<.001$ \\
\hline Variance (observation level) & 0.053 & $<.001$ & 0.053 & $<.001$ \\
\hline Variance (player level) & 0.016 & $<.001$ & 0.016 & $<.001$ \\
\hline
\end{tabular}

\footnotetext{
she played.

${ }^{\mathrm{c}} \mathrm{BMI}$ : body mass index.

${ }^{\mathrm{d}}$ The value is equal to the value of Pokémon GO or not multiplied by built environment.
}

${ }^{\mathrm{a}}$ If the data belonged to the date before the participant played Pokémon GO, this value would be 0 . Otherwise, it would be 1 .

${ }^{b}$ If the data belonged to the date before the participant played Pokémon GO, this value would be 0. Otherwise, it would be the number of days he or

\section{Discussion}

\section{Principal Results and Comparison With Prior Work}

This study reported that after the game installation, average daily walking and running distances of Hong Kong Pokémon GO players increased by $18.1 \%(0.96 \mathrm{~km}$, approximately 1200 steps) compared with the period before installation, which spanned for over a period of 35 days. These results were largely consistent with those of previous studies that were conducted in USA. For example, Howe et al found that the average number of daily steps for Pokémon GO players during the first week of installation increased by 955 steps [21]. Althoff and his colleagues indicated that Pokémon GO led to significant increases of more than 25\% (1473 steps per day over a period of 30 days) [22]. These studies conducted in USA and the study conducted in Asia study showed that playing Pokémon GO was associated with an increase in physical activity in the first month players played the game. These results supported the idea that Pokémon GO may improve public health by promoting physical activity $[32,33,38,39]$.

Our results showed that the increases in daily walking and running distances attenuated over time. This finding is also congruent with those of the previous studies conducted in USA [21,22]. However, the speed of attenuation was different between the study conducted by us, in Asia, and those conducted in USA. Although Howe et al [21] reported that the association was no longer observed after 6 weeks (42 days), our results indicated that the association disappeared faster, in 24 days, with Hong Kong players. This may be because Hong Kong is a relatively fast-paced society [40], which may make it easier for people to lose interest in the game. The high-density built environment, which lacks spacious places for playing location-based AR games, could also be another reason for this difference. If we wish to maximize the positive benefit from the game, initiatives should be taken to find ways to slow down attenuation.

From multilevel models, we found that total rainfall, bright sunshine duration, mean air temperature, and mean wind speed were significantly related to Pokémon GO players' physical activity levels. The link between the weather and physical activity is well established. An increased duration of daily bright sunshine could increase daily walking activity [41] and participation in outdoor activities [42]; higher rainfall and wind speed are likely to be associated with lower physical activity levels [43-46]; the temperature could have different impacts on physical activities across areas and seasons [47]. For the season during which we conducted our study in Hong Kong, we found that the duration of bright sunshine was significantly associated with increased daily walking and running distances, whereas total rainfall, mean air temperature, and mean wind speed were negatively correlated with the distances. To the best of our knowledge, this is the first study that controlled the weather variables to provide a more precise relationship between Pokémon GO behaviors and physical activity levels. On December 7, 2017, the new version of Pokémon GO was introduced and included weather features, in addition to an in-game weather visual map, weather near Pokémon players will impact Pokémon in a variety of ways. This update made weather an even more important factor for the players [48].

The relationship between physical activity and built environment has been well investigated in recent decades [17]. As a location-based AR game, Pokémon GO is highly connected with built environment and both of these variables could be associated with players' physical activity levels. In previous studies, however, built environment was not taken into consideration or they showed little impact on physical activity levels [21,22]. We examined Pokémon GO together with built environment and found that green space had a significant positive relationship with daily walking and running distances (Table 4). This result indicated that Pokémon GO may have encouraged players to use the green space around them to engage in physical activity. Nature-based recreation has decreased by $25 \%$ in the last 40 years [49], endangering the health benefits associated with nature and green space [50]. To solve this problem, Pokémon GO shows great potential to build connections between green space and opportunities for physical activity. 
By controlling for the weather variable at the observation level and for demographics and built environment at the player level, our results showed that players with shorter daily walking and running distances exhibited stronger associations with Pokémon GO. These associations also lasted longer than players with relatively longer distances before installation. This result confirmed the previous findings from the studies conducted in USA that Pokémon GO is able to reach low activity populations $[22,26]$. Governments and public health agencies may consider the possibility of using location-based AR technology to improve physical activity and public health.

\section{Contributions}

To the best of our knowledge, this study was one of the earliest and the only studies conducted during the Pokémon GO craze (from July 2016 to August 2016). This work offers 3 main contributions. First, we combined field surveys with automatically recorded physical activity data from mobile devices. The field study gave us an idea of who was playing the game outside and engaging in physical activity. Second, this paper was the first paper that investigated the relationship between Pokémon GO and physical activity with the weather and built environment added as covariates. Third, the difference in associations between Pokémon GO use and physical activity among different players was investigated. Such information is important to enhance the positive impact brought by future games or interventions. Further, as the first objective physical activity study of Pokémon GO in Asia, this study provided evidence together with other previous studies, which indicated that Pokémon GO was associated with short-term increases in physical activity levels.

\section{Limitations}

Our study had some limitations. First, our study population was a representative of active Pokémon GO players; it was not a random sample of the Hong Kong population. It could not represent all the Pokémon GO players in Hong Kong. It is possible that some players may have only played at midnight (or during other irregular times), which was not within our survey time, or some people may have only played Pokémon $\mathrm{GO}$ in a place that was dissimilar to our study areas.

Second, this was a one group pretest-posttest design study. We acknowledge that we lack a control group; however, our data indicate that Pokémon GO alone was associated with physical activity changes in participants. During the study time, there was no campaign, parade, or other large-scale physical activity-related event that happened in Hong Kong. There were also no dramatic weather changes that could have led to increases in physical activity levels.

Further, we used daily walking and running distances as a proxy measurement of physical activity. We do acknowledge the possibility that other physical activities (eg, swimming and basketball) were likely to be not recorded if the players did not carry their phones during those activities.

\section{Conclusions}

We studied 210 Pokémon GO players in Hong Kong during the Pokémon GO craze of 2016. Our results indicated that after the installation of the game, the average daily walking and running distances increased by $18.1 \%$ (0.96 km, approximately 1200 steps) compared with the levels measured before the installation. However, this association attenuated over time and was estimated to disappear after 24 days. The results of multilevel models indicated that the weather should be considered in this kind of research and the association between Pokémon GO use and physical activity was stronger among less physically active people compared with physically active people. We found that a game like Pokémon GO has the potential to build new links between humans and green space and to encourage people to engage in physical activity outdoor. Having a better understanding of the relationship between Pokémon GO use and physical activity may cast light on the future efforts needed to promote public health on a global scale.

\section{Acknowledgments}

The authors thank Hui Lin, PhD, of The Chinese University of Hong Kong for advice on the field study.

\section{Authors' Contributions}

BDM, GS, and SLN designed the project. BDM, SLN, and GS collected data. BDM, TS, and MZ analyzed the data. BDM and SLN wrote the manuscript. All authors contributed to the manuscript. TS, GS, IK, and JZ provided methodological guidance. SLN provided financial support for the data collection.

\section{Conflicts of Interest}

All authors declare no financial relationships with any organizations that might have an interest in the submitted work and no other relationships or activities that could appear to have influenced the submitted work.

\section{References}

1. Smith C. DMR. 80 Amazing pokemon go statistics URL: https://expandedramblings.com/index.php/pokemon-go-statistics/ [accessed 2017-11-30] [WebCite Cache ID 6vMh1O2dB]

2. The Pokémon GO team. 2017. Adventures Await! Pokémon GO URL: https://pokemongolive.com/en/post/ adventureweek2017 [accessed 2017-11-30] [WebCite Cache ID 6vMh7JdtX]

3. Caspersen CJ, Powell KE, Christenson GM. Physical activity, exercise, and physical fitness: definitions and distinctions for health-related research. Public Health Rep 1985 Apr;100(2):126-131 [FREE Full text] [Medline: 3920711] 
4. Pate RR, Pratt M, Blair SN, Haskell WL, Macera CA, Bouchard C, et al. Physical activity and public health. A recommendation from the Centers for Disease Control and Prevention and the American College of Sports Medicine. JAMA 1995 Feb 1;273(5):402-407. [Medline: 7823386$]$

5. World Health Organization. 2010. Global recommendations on physical activity for health URL: http://www.who.int/ dietphysicalactivity/factsheet recommendations/en/ [accessed 2017-11-30] [WebCite Cache ID 6vMhN2meJ]

6. Sallis JF, Bauman A, Pratt M. Environmental and policy interventions to promote physical activity. Am J Prev Med 1998 Nov;15(4):379-397. [Medline: 9838979]

7. Marcus BH, Nigg CR, Riebe D, Forsyth LH. Interactive communication strategies: implications for population-based physical-activity promotion. Am J Prev Med 2000 Aug;19(2):121-126. [Medline: 10913903]

8. Hallal PC, Andersen LB, Bull FC, Guthold R, Haskell W, Ekelund U, et al. Global physical activity levels: surveillance progress, pitfalls, and prospects. Lancet 2012 Jul 21;380(9838):247-257. [doi: 10.1016/S0140-6736(12)60646-1] [Medline: 22818937]

9. Powell LM, Slater S, Chaloupka FJ, Harper D. Availability of physical activity-related facilities and neighborhood demographic and socioeconomic characteristics: a national study. Am J Public Health 2006 Sep;96(9):1676-1680. [doi: 10.2105/AJPH.2005.065573] [Medline: 16873753 ]

10. Azevedo MR, Araújo CLP, Reichert FF, Siqueira FV, da SMC, Hallal PC. Gender differences in leisure-time physical activity. Int J Public Health 2007;52(1):8-15 [FREE Full text] [Medline: 17966815]

11. Borodulin K, Sipilä N, Rahkonen O, Leino-Arjas P, Kestilä L, Jousilahti P, et al. Socio-demographic and behavioral variation in barriers to leisure-time physical activity. Scand J Public Health 2016 Feb;44(1):62-69. [doi: 10.1177/1403494815604080] [Medline: 26392420]

12. Frank LD, Andresen MA, Schmid TL. Obesity relationships with community design, physical activity, and time spent in cars. Am J Prev Med 2004 Aug;27(2):87-96. [doi: 10.1016/j.amepre.2004.04.011] [Medline: 15261894]

13. Blair SN, Church TS. The fitness, obesity, and health equation: is physical activity the common denominator? JAMA 2004 Sep 08;292(10):1232-1234. [doi: 10.1001/jama.292.10.1232] [Medline: 15353537]

14. Lewis LK, Maher C, Belanger K, Tremblay M, Chaput J, Olds T. At the Mercy of the Gods: Associations Between Weather, Physical Activity, and Sedentary Time in Children. Pediatr Exerc Sci 2016 Feb;28(1):152-163. [doi: 10.1123/pes.2015-0076] [Medline: 26098393]

15. Tucker P, Gilliland J. The effect of season and weather on physical activity: a systematic review. Public Health 2007 Dec;121(12):909-922. [doi: 10.1016/j.puhe.2007.04.009] [Medline: 17920646]

16. Wu Y, Luben R, Wareham N, Griffin S, Jones AP. Weather, day length and physical activity in older adults: Cross-sectional results from the European Prospective Investigation into Cancer and Nutrition (EPIC) Norfolk Cohort. PLoS One 2017;12(5):e0177767 [FREE Full text] [doi: 10.1371/journal.pone.0177767] [Medline: 28562613]

17. Handy SL, Boarnet MG, Ewing R, Killingsworth RE. How the built environment affects physical activity: views from urban planning. Am J Prev Med 2002 Aug;23(2 Suppl):64-73. [Medline: 12133739]

18. Gebel K, Ding D, Foster C, Bauman AE, Sallis JF. Improving current practice in reviews of the built environment and physical activity. Sports Med 2015 Mar;45(3):297-302. [doi: 10.1007/s40279-014-0273-8] [Medline: 25315457]

19. Brownson RC, Hoehner CM, Day K, Forsyth A, Sallis JF. Measuring the built environment for physical activity: state of the science. Am J Prev Med 2009 Apr;36(4 Suppl):S99-123.e12 [FREE Full text] [doi: 10.1016/j.amepre.2009.01.005] [Medline: 19285216$]$

20. Baranowski T, Blumberg F, Buday R, DeSmet A, Fiellin LE, Green CS, et al. Games for Health for Children-Current Status and Needed Research. Games Health J 2016 Feb;5(1):1-12 [FREE Full text] [doi: 10.1089/g4h.2015.0026] [Medline: 26262772]

21. Howe KB, Suharlim C, Ueda P, Howe D, Kawachi I, Rimm EB. Gotta catch'em all! Pokémon GO and physical activity among young adults: difference in differences study. BMJ 2016 Dec 13;355:i6270 [FREE Full text] [Medline: 27965211]

22. Althoff T, White RW, Horvitz E. Influence of Pokémon Go on Physical Activity: Study and Implications. J Med Internet Res 2016 Dec 06;18(12):e315 [FREE Full text] [doi: 10.2196/jmir.6759] [Medline: 27923778]

23. Mosendz P. Bloomberg. Counting the extra footsteps from Pokémon Go mania URL: https://www.bloomberg.com/news/ $\underline{\text { articles/2016-07-15/counting-the-extra-footsteps-from-pokemon-go-mania [accessed 2017-11-30] [WebCite Cache ID }}$ 6vMhPIPUM]

24. Nigg CR, Mateo DJ, An J. Pokémon GO May Increase Physical Activity and Decrease Sedentary Behaviors. Am J Public Health 2017 Jan;107(1):37-38. [doi: 10.2105/AJPH.2016.303532] [Medline: 27854536]

25. Wagner-Greene V, Wotring A, Castor T, Kruger J, Mortemore S, Dake J. Pokémon GO: Healthy or Harmful? Am J Public Health 2017 Jan;107(1):35-36. [doi: 10.2105/AJPH.2016.303548] [Medline: 27925813]

26. Wong FY. Influence of Pokémon Go on physical activity levels of university players: a cross-sectional study. Int $\mathbf{J}$ Health Geogr 2017 Feb 22;16(1):8 [FREE Full text] [doi: 10.1186/s12942-017-0080-1] [Medline: 28228102]

27. Rasche P, Schlomann A, Mertens A. Who Is Still Playing Pokémon Go? A Web-Based Survey. JMIR Serious Games 2017 Apr 05;5(2):e7 [FREE Full text] [doi: 10.2196/games.7197] [Medline: 28381393] 
28. Marquet O, Alberico C, Adlakha D, Hipp JA. Examining Motivations to Play Pokémon GO and Their Influence on Perceived Outcomes and Physical Activity. JMIR Serious Games 2017 Oct 24;5(4):e21 [FREE Full text] [doi: 10.2196/games.8048] [Medline: 29066423]

29. Lindqvist A, Castelli D, Hallberg J, Rutberg S. The Praise and Price of Pokémon GO: A Qualitative Study of Children's and Parents' Experiences. JMIR Serious Games 2018 Jan 03;6(1):e1 [FREE Full text] [doi: 10.2196/games.8979] [Medline: $\underline{29298750}]$

30. Barbieri S, Vettore G, Pietrantonio V, Snenghi R, Tredese A, Bergamini M, et al. Pedestrian Inattention Blindness While Playing Pokémon Go as an Emerging Health-Risk Behavior: A Case Report. J Med Internet Res 2017 Apr 01;19(4):e86 [FREE Full text] [doi: 10.2196/jmir.6596] [Medline: 28365563]

31. Ono S, Ono Y, Michihata N, Sasabuchi Y, Yasunaga H. Effect of Pokémon GO on incidence of fatal traffic injuries: a population-based quasi-experimental study using the national traffic collisions database in Japan. Inj Prev 2017 Oct 12:042503. [doi: 10.1136/injuryprev-2017-042503] [Medline: 29025874]

32. LeBlanc AG, Chaput J. Pokémon Go: A game changer for the physical inactivity crisis? Prev Med 2016 Nov 14:235-237. [doi: 10.1016/j.ypmed.2016.11.012] [Medline: 27856340]

33. McCartney M. Margaret McCartney: Game on for Pokémon Go. BMJ 2016 Aug 09;354:i4306 [FREE Full text] [doi: 10.1136/bmj.i4306]

34. Kogan L, Hellyer P, Duncan C, Schoenfeld-Tacher R. A pilot investigation of the physical and psychological benefits of playing Pokémon GO for dog owners. Computers in Human Behavior 2017 Nov;76:431-437 [FREE Full text] [doi: 10.1016/j.chb.2017.07.043]

35. United Nations. 2011. World Population Prospects The 2010 Revision URL: http://www.un.org/en/development/desa/ population/publications/pdf/trends/WPP2010/WPP2010 Volume-I Comprehensive-Tables.pdf[WebCite Cache ID 6y5W4w39P]

36. Giridharan R, Ganesan S, Lau S. Daytime urban heat island effect in high-rise and high-density residential developments in Hong Kong. Energy and Buildings 2004 Jun;36(6):525-534 [FREE Full text] [doi: 10.1016/j.enbuild.2003.12.016]

37. Sun G, Zacharias J, Ma B, Oreskovic N. How do metro stations integrate with walking environments? Results from walking access within three types of built environment in Beijing. Cities 2016 Jul;56:91-98 [FREE Full text] [doi: 10.1016/j.cities.2016.03.001]

38. Tateno M, Skokauskas N, Kato TA, Teo AR, Guerrero APS. New game software (Pokémon Go) may help youth with severe social withdrawal, hikikomori. Psychiatry Res 2016 Dec 30;246:848-849. [doi: 10.1016/j.psychres.2016.10.038] [Medline: 27817905]

39. Wise J. Pokémon Go's health benefits seem short lived. BMJ 2016 Dec 13:i6684 [FREE Full text] [doi: 10.1136/bmj.i6684]

40. Levine R, Norenzayan A. The Pace of Life in 31 Countries. Journal of Cross-Cultural Psychology 2016 Jul 26;30(2):178-205 [FREE Full text] [doi: 10.1177/0022022199030002003]

41. Klenk J, Büchele G, Rapp K, Franke S, Peter R, ActiFE Study Group. Walking on sunshine: effect of weather conditions on physical activity in older people. J Epidemiol Community Health 2012 May;66(5):474-476. [doi:

10.1136/jech.2010.128090] [Medline: 21325149]

42. Lindsey G, Han Y, Wilson J, Yang J. Neighborhood Correlates of Urban Trail Use. J Phys Act Health 2006 Feb;3(s1):S139-S157. [doi: 10.1123/jpah.3.s1.s139] [Medline: 28834516]

43. Brodersen NH, Steptoe A, Williamson S, Wardle J. Sociodemographic, developmental, environmental, and psychological correlates of physical activity and sedentary behavior at age 11 to 12. Ann Behav Med 2005 Feb;29(1):2-11. [doi: 10.1207/s15324796abm2901 2] [Medline: 15677295$]$

44. Harrison F, Jones AP, Bentham G, van SEMF, Cassidy A, Griffin SJ. The impact of rainfall and school break time policies on physical activity in 9-10 year old British children: a repeated measures study. Int J Behav Nutr Phys Act 2011 May 24;8:47 [FREE Full text] [doi: 10.1186/1479-5868-8-47] [Medline: 21609441]

45. Currie JL, Develin E. Stroll your way to well-being: a survey of the perceived benefits, barriers, community support, and stigma associated with pram walking groups designed for new mothers, Sydney, Australia. Health Care Women Int 2002 Dec;23(8):882-893. [doi: 10.1080/07399330290112380] [Medline: 12487703 ]

46. Tu W, Stump TE, Damush TM, Clark DO. The effects of health and environment on exercise-class participation in older, urban women. J Aging Phys Act 2004 Oct;12(4):480-496. [Medline: 15851821]

47. Chan CB, Ryan DAJ, Tudor-Locke C. Relationship between objective measures of physical activity and weather: a longitudinal study. Int J Behav Nutr Phys Act 2006 Aug 07;3:21 [FREE Full text] [doi: 10.1186/1479-5868-3-21] [Medline: 16893452]

48. Pokemongolive.com. Developer Insights: Introducing Dynamic Weather Gameplay and Battle Parties URL: https:/ /pokemongolive.com/en/post/decdevupdate-weather/ [accessed 2018-03-22] [WebCite Cache ID 6y7KhYkH2]

49. Pergams ORW, Zaradic PA. Evidence for a fundamental and pervasive shift away from nature-based recreation. Proc Natl Acad Sci U S A 2008 Feb 19;105(7):2295-2300 [FREE Full text] [doi: 10.1073/pnas.0709893105] [Medline: 18250312]

50. Lee ACK, Maheswaran R. The health benefits of urban green spaces: a review of the evidence. J Public Health (Oxf) 2011 Jun;33(2):212-222. [doi: 10.1093/pubmed/fdq068] [Medline: 20833671] 


\section{Abbreviations}

BMI: body mass index

AR: augmented reality

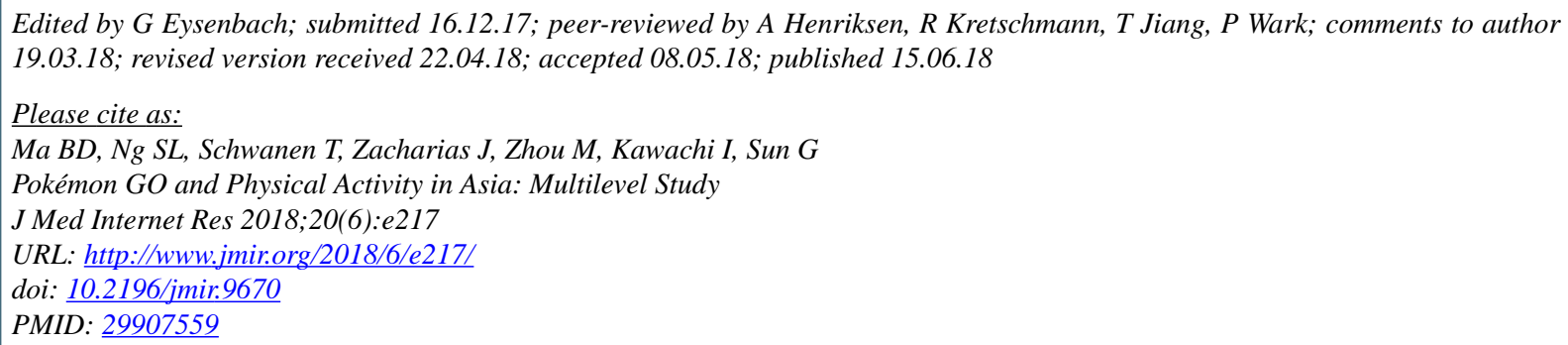

CBen D Ma, Sai Leung Ng, Tim Schwanen, John Zacharias, Mudi Zhou, Ichiro Kawachi, Guibo Sun. Originally published in the Journal of Medical Internet Research (http://www.jmir.org), 15.06.2018. This is an open-access article distributed under the terms of the Creative Commons Attribution License (https://creativecommons.org/licenses/by/4.0/), which permits unrestricted use, distribution, and reproduction in any medium, provided the original work, first published in the Journal of Medical Internet Research, is properly cited. The complete bibliographic information, a link to the original publication on http://www.jmir.org/, as well as this copyright and license information must be included. 